\title{
High-resolution hydraulic parameter maps for surface soils in tropical South America
}

\author{
T. R. Marthews ${ }^{1}$, C. A. Quesada ${ }^{2}$, D. R. Galbraith ${ }^{3}$, Y. Malhi ${ }^{1}$, C. E. Mullins ${ }^{4}$, M. G. Hodnett ${ }^{5}$, and I. Dharssi ${ }^{6}$ \\ ${ }^{1}$ Environmental Change Institute, School of Geography and the Environment, University of Oxford, Oxford OX1 3QY, UK \\ ${ }^{2}$ Instituto Nacional de Pesquisas da Amazônia, 69060-001 Manaus, Brazil \\ ${ }^{3}$ School of Geography, University of Leeds, Leeds LS2 9JT, UK \\ ${ }^{4} 44$ Leadervale Rd., Edinburgh EH16 6PA, UK \\ ${ }^{5}$ Higher Park, Pennymoor, Tiverton, Devon EX16 8LL, UK \\ ${ }^{6}$ Bureau of Meteorology, Melbourne 3001, Australia
}

Correspondence to: T. R. Marthews (toby.marthews@ouce.ox.ac.uk)

Received: 28 September 2013 - Published in Geosci. Model Dev. Discuss.: 17 December 2013

Revised: 3 March 2014 - Accepted: 19 March 2014 - Published: 6 May 2014

\begin{abstract}
Modern land surface model simulations capture soil profile water movement through the use of soil hydraulics sub-models, but good hydraulic parameterisations are often lacking, especially in the tropics. We present muchimproved gridded data sets of hydraulic parameters for surface soil for the critical area of tropical South America, describing soil profile water movement across the region to $30 \mathrm{~cm}$ depth. Optimal hydraulic parameter values are given for the Brooks and Corey, Campbell, van GenuchtenMualem and van Genuchten-Burdine soil hydraulic models, which are widely used hydraulic sub-models in land surface models. This has been possible through interpolating soil measurements from several sources through the SOTERLAC soil and terrain data base and using the most recent pedotransfer functions (PTFs) derived for South American soils. All soil parameter data layers are provided at 15 arcsec resolution and available for download, this being 20x higher resolution than the best comparable parameter maps available to date. Specific examples are given of the use of PTFs and the importance highlighted of using PTFs that have been locally parameterised and that are not just based on soil texture. We discuss current developments in soil hydraulic modelling and how high-resolution parameter maps such as these can improve the simulation of vegetation development and productivity in land surface models.
\end{abstract}

\section{Introduction}

Ecosystem water cycles are fundamental to our understanding of how vegetation develops, and how plants respond to periods of high and low water availability. Plants in all ecosystems obtain most of their water through soil, and the study of water movement through the soil matrix has a long history in both ecology and agriculture (Childs, 1969; Marshall et al., 1996; Leigh, 1999). Soil properties in general are widely recognised as one of the critical factors controlling ecological differences between and within biomes (Phillips et al., 1994, 2004; Leigh, 1999; Aragão et al., 2009; Lloyd et al., 2009; Quesada et al., 2012), as are soil hydraulic properties in particular (Marshall et al., 1996; Tomasella and Hodnett, 1998; Tomasella et al., 2000; Hodnett and Tomasella, 2002).

Soil information is a crucial input for vegetation and land surface modelling applications: soil properties strongly influence water exchange between the land surface and atmosphere as well as growth processes such as regeneration (e.g. Leigh, 1999; Marthews et al., 2008; Dharssi et al., 2009; Dadson et al., 2011). From a modelling perspective, soil water movement is the result of several overlapping processes, usually simulated by distinct hydrological submodels (Dadson et al., 2011). At the particle scale within individual soil samples we find that capillary processes dominate (Townend et al., 2001; Hodnett and Tomasella, 2002; Fredlund et al., 2012); at the soil profile or site scale 
considerations of bypass flow arise (Marshall et al., 1996; Marthews et al., 2008), at the landscape scale relative topographic position and groundwater flow are the overriding factors (Dadson et al., 2011) and at the regional scale river routing and other transport processes can overwhelm all other effects (Dadson and Bell, 2010; Dadson et al., 2011). These different processes are all represented within land surface models, although with varying levels of sophistication (e.g. in the JULES model, Best et al., 2011).

For landscape-scale gridded model runs, pre-calculated ancillary files are required to provide the spatially varying parameter estimates required by hydrological sub-models (e.g. Dharssi et al., 2009; Castanho et al., 2013). The most widely used, publicly available set of global ancillary files are currently the IGBP-DIS parameter maps (Global Soil Data Task Group, 2000), however at 5 arcmin resolution (approximately $10 \mathrm{~km}$ at the Equator), these maps are now considered fairly coarse (Ke et al., 2012). Land surface models are now being applied at increasingly high spatial resolution both offline as well as coupled to climate models (Ke et al., 2012), which is necessary to capture the fine-scale dynamics of ecosystem development for realistic modelling of ecosystem productivity and development (Malhi and Wright, 2004; Marthews et al., 2008).

Tropical South America is the most intensively studied tropical region (Malhi and Wright, 2004) so we have taken this region as our focus. Across the tropical zone, the availability of soil-related data for running high-detail simulations has historically been low (Tomasella and Hodnett, 1998; Tomasella et al., 2000), but in recent years this zone has been recognised as one of the critical "driver" biomes of the world's climate system and the situation is fast improving (Leigh, 1999; Malhi and Wright, 2004; Phillips et al., 2004). Much progress has been made in the availability of highquality soil information (e.g. the SOil and TERrain data base SOTER, Dijkshoorn et al., 2005) and it is now possible to construct ancillary files of much higher resolution and reliability. Additionally, with ever more research groups gaining the capacity to carry out large-scale gridded simulations on a routine basis, there is an increasing need for spatially explicit parameter maps with which to drive those simulations (e.g. Castanho et al., 2013).

Soil hydraulic models are the components of land surface models that control and simulate water movement through the soil matrix (Table 1). Parameters for fine-scale soil hydraulic models are generally derived from soil profile data using pedotransfer functions (PTFs), which are equations used to estimate unavailable soil variables from closely related and more available soil properties such as texture and dry bulk density (Table 2). There is much current debate on the suitability of hydraulic models and PTFs in the tropics and we make recommendations for their use in the context of tropical South America (Fig. 1). Our hydraulic parameters may therefore be used to produce much more robust simulations of soil water dynamics for this region. Downloadable

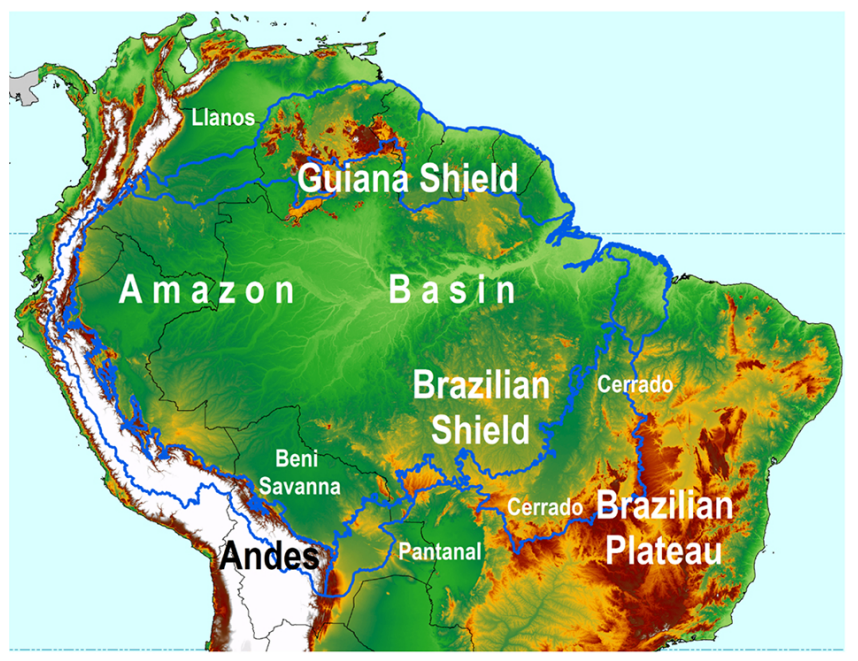

Fig. 1. Physical map of tropical South America (based on the HydroSHEDS Digital Elevation Model, Lehner et al., 2006). National borders and the outline of Amazonia sensu stricto are shown (Eva et al., 2005).

"model-ready" data grids of parameter values are produced from this analysis, in appropriate formats for use in a wide variety of land surface modelling applications. Finally, we discuss current developments in soil hydraulic modelling in general and identify ways in which these models can benefit from higher-resolution parameter maps such as these.

\section{Methods}

\subsection{Soil hydraulic models}

Water movement through saturated soil is described by Darcy's law, which holds that the vertical rate of water movement is the product of a gradient in hydraulic potential and the soil hydraulic conductivity $k$ (Childs, 1969; Dullien, 1992; Marshall et al., 1996). In unsaturated soil Darcy's law may be generalised to the Richards equation (Marshall et al., 1996), which involves $k$ becoming a function of the soil matric potential $\psi$ (aka matric tension, equivalent to capillary pressure head), where $\psi$ is the component of hydraulic potential when any differences in elevation are ignored (Marshall et al., 1996; Mullins, 2001). The relationships between $\psi, k$ and volumetric soil water content $\theta$ (unfrozen) can be described by two closely related curves called the soil water characteristic (SWC) and the soil hydraulic conductivity curve (HCC) (Fig. 2), which together describe the hydraulic model of the soil. In this study we use the four most widely used soil hydraulic models (Table 1).

\subsection{South American soils}

We focus on the soils of tropical South America (taken as the area from Panama to the tropic line from Antofagasta, Chile, 


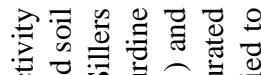

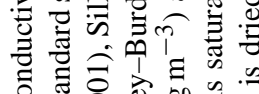

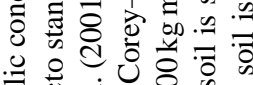

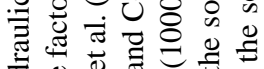

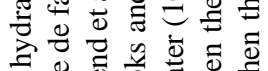

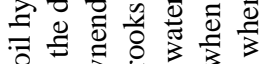

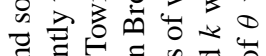

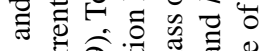
๙ 므

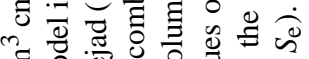

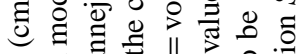

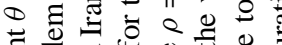

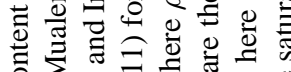

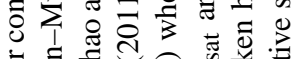

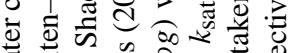

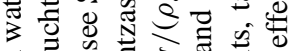
न

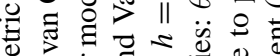

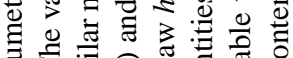
三 可

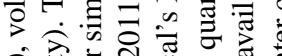
बं $\overrightarrow{0}$ d

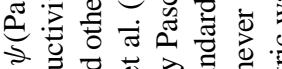
흘 可志志

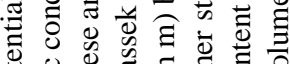

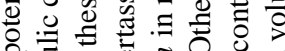

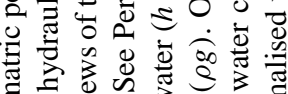

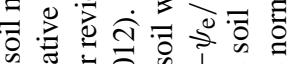

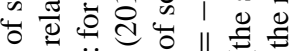
है ए.

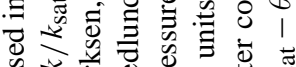

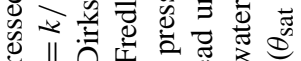

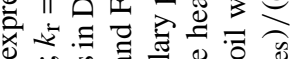
क : 屯 क छ $\Rightarrow$ o

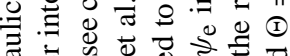

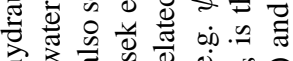

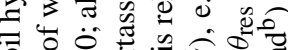
은 च 듕 क्ष

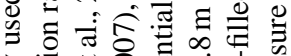

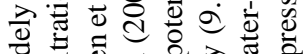

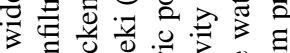

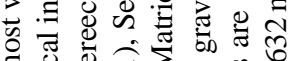

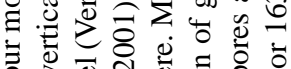

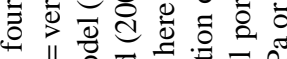

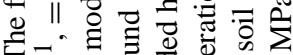

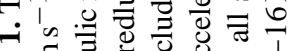

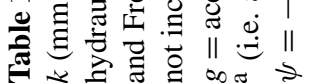

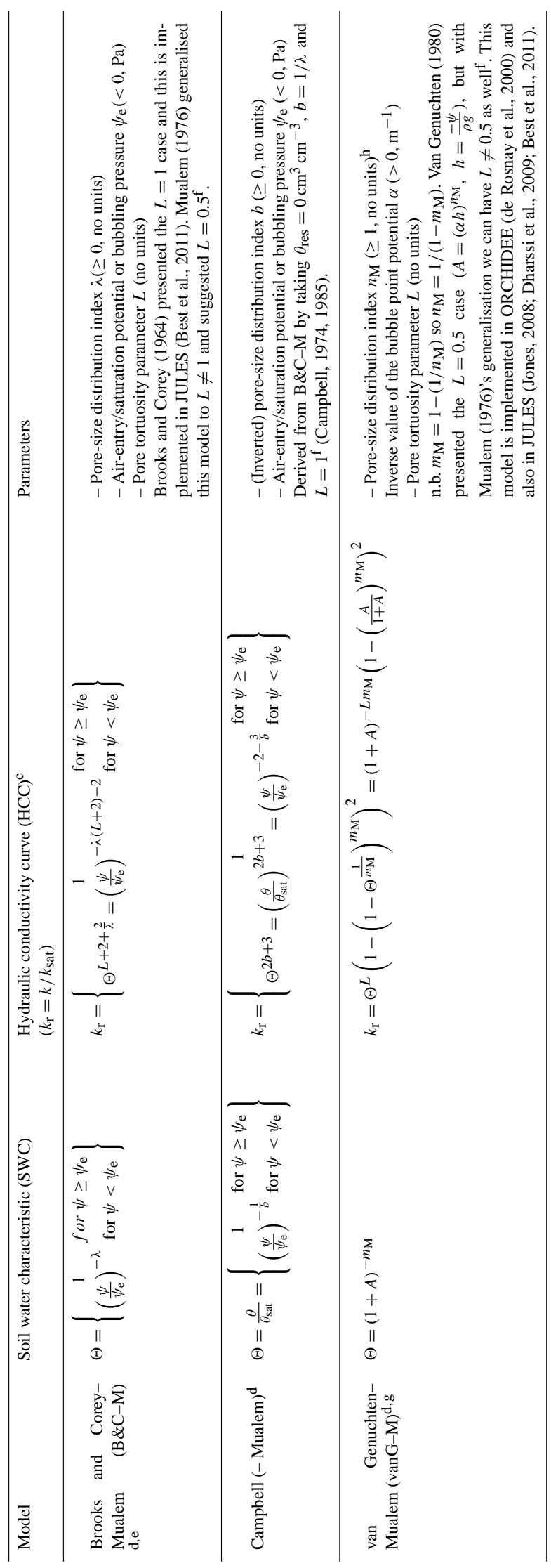

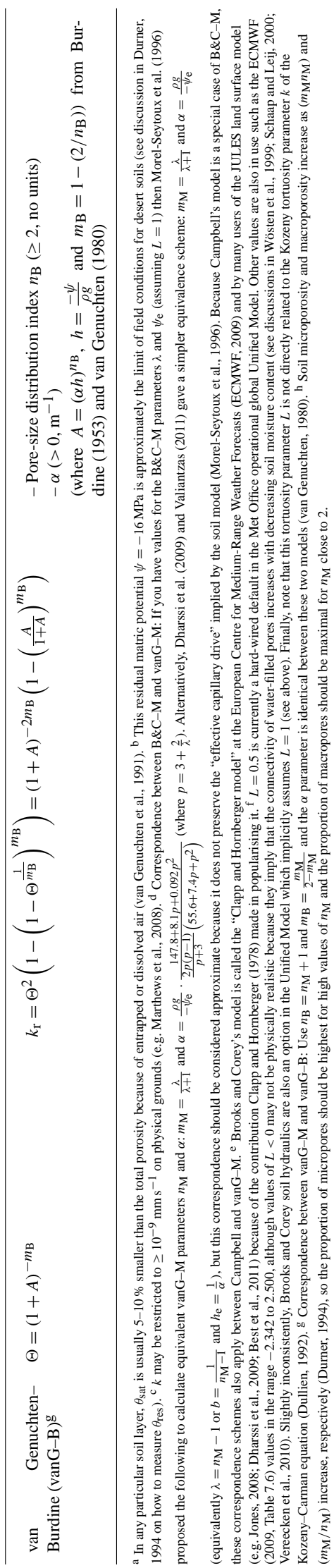


(a) Soil Water Characteristic (SWC)

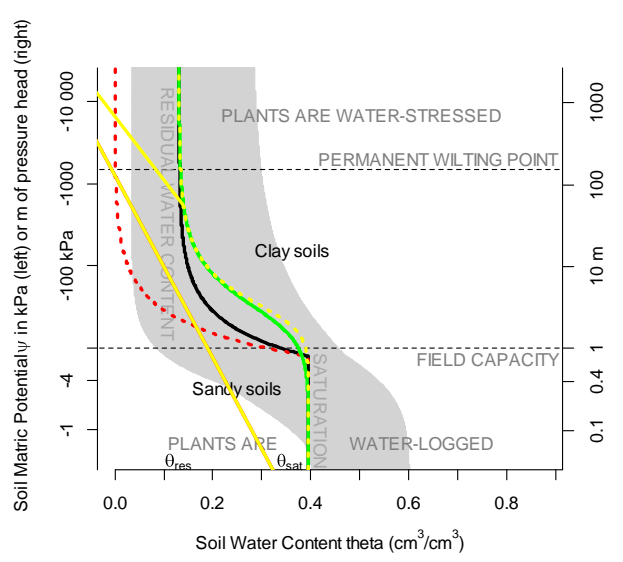

(b) Hydraulic Conductivity Curve (HCC)

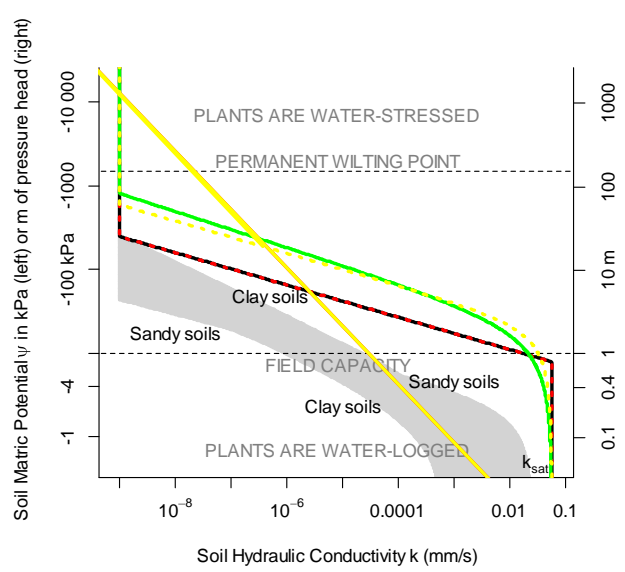

Fig. 2. An example soil water characteristic (SWC) (a) and corresponding hydraulic conductivity curve (HCC) (b) (Childs, 1969; Townend et al., 2001; Dirksen 2001) for a silt loam soil with no shrinkage or hysteresis (example from van Genuchten, 1980). When the soil is saturated with water (e.g. just after heavy rain), $\theta=\theta_{\text {sat }}$ and $k=k_{\text {sat }}$ (see Table 1 for these quantities). As the soil begins to dry and becomes unsaturated, the soil moisture content and conductivity fall rapidly until gravity drainage ceases and field capacity is reached (usually a few days after rain) (Fredlund et al., 2012). If drying continues, plants become increasingly water-stressed and will begin to exhibit damage at

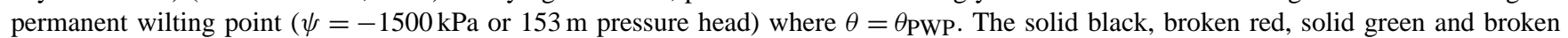
yellow curves are the appropriate Brooks and Corey, Campbell, van Genuchten-Mualem and van Genuchten-Burdine models for this soil, respectively (Table 1; Brooks and Corey coincides exactly with Campbell on $\mathbf{b}$ ). The grey bands show the range of values across tropical soil categories considered by Hodnett and Tomasella (2002), assuming $k_{\text {sat }}$ values from the pedotransfer function of Cosby et al. (1984) (Table 2), from which it may be seen that this example soil has a relatively low saturated water content but high hydraulic conductivity. Unrealistically small values of $k_{\text {unsat }}$ are avoided by restricting $k_{\text {unsat }}$ to $\geq 10^{-9} \mathrm{~mm} \mathrm{~s}^{-1}$ (Marthews et al., 2008).

to São Paulo, Brazil, excluding the Galápagos Archipelago, and the outlying islands Cocos Is., Malpelo Is., Fernando de Noronha, St Peter and St Paul, Trindade and Martim Vaz and Rocas Atoll, Fig. 1). Tropical soils cover a huge range of types and this area is no exception (Ashton, 2004), with parent material varying from the Precambrian rocks of the Guiana and Brazilian Shields to the much younger Cenozoic geology of the Andes and western Amazon (Quesada et al., 2011).

Soil profile measurements were collected from three sources: (i) Quesada et al. (2010) collected data throughout the area as part of the projects RAINFOR http://www. rainfor.org/ and TROBIT www.geog.leeds.ac.uk/groups/ trobit/, (ii) data from the large RADAMBRASIL project (de Negreiros et al., 2009) as supplemented by Cooper et al. (2005) provided good coverage of Brazil and (iii) data from the International Soil Reference and Information Centre (ISRIC) was used to cover the remaining area (Batjes, 2000). We focused on surface soil for this analysis because there was insufficient data for adequate mapping of deeper soil: all soil profile data from below $30 \mathrm{~cm}$ depth were discarded from these sources, which left a total data base of 7620 profile measurements across tropical South America. The soil areas of SOTERLAC (Dijkshoorn et al., 2005) were used, supplemented by data for the same polygons from Batjes (2010).
Over these profile measurements, values for cation exchange capacity (CEC) were used if available from Quesada et al. (2010) and the corresponding polygon in Batjes (2010) (68.8\% of points), otherwise values $10.1 \mathrm{cmol} \mathrm{kg}^{-1}$ and $45.7 \mathrm{cmol} \mathrm{kg}^{-1}$ were substituted for low and high activity clays, respectively (Hodnett and Tomasella, 2002), following the low- and high-activity categories in Batjes (2010) (Fig. 3). Values for soil organic carbon (SOC) were taken from RADAMBRASIL, Cooper et al. (2005) and Quesada et al. (2010). Values for dry bulk density (DBD) were used if possible from Batjes (2000) (1.2\% of points), otherwise a value of $\max (0.05,1.578-(0.054 \times(\mathrm{SOC} / 10))-$ $(0.006 \times$ SIPC $)-(0.004 \times$ CLPC $)) \mathrm{g} \mathrm{cm}^{-3}$ was substituted (Tomasella and Hodnett, 1998) (a further $90.0 \%$ of points; all variables and units are given in Table 2).

\subsection{Spatial analyses}

All GIS data analyses were carried out in ArcGIS 10.0 (Esri Inc., Redlands, CA). Taking the SOTERLAC polygons as the base areal units, mean values of available soil properties were calculated and assigned to the polygon containing those points. If no profile measurements were available for a particular polygon, a taxotransfer rule was followed with a mean assigned from all profile measurements in the same soil type (taken from Dijkshoorn et al., 2005). In the few cases where no measurements were available from a particular soil 


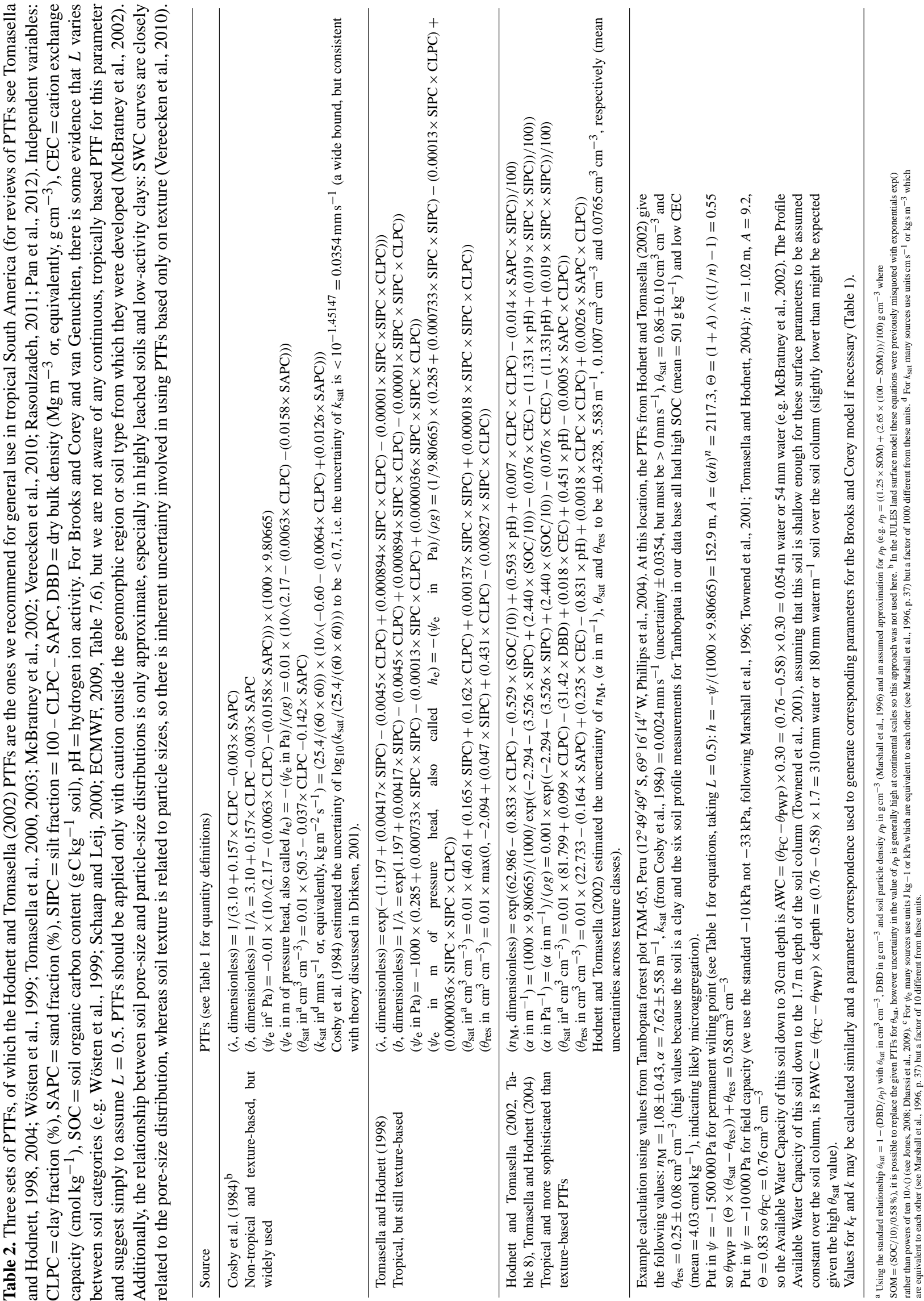




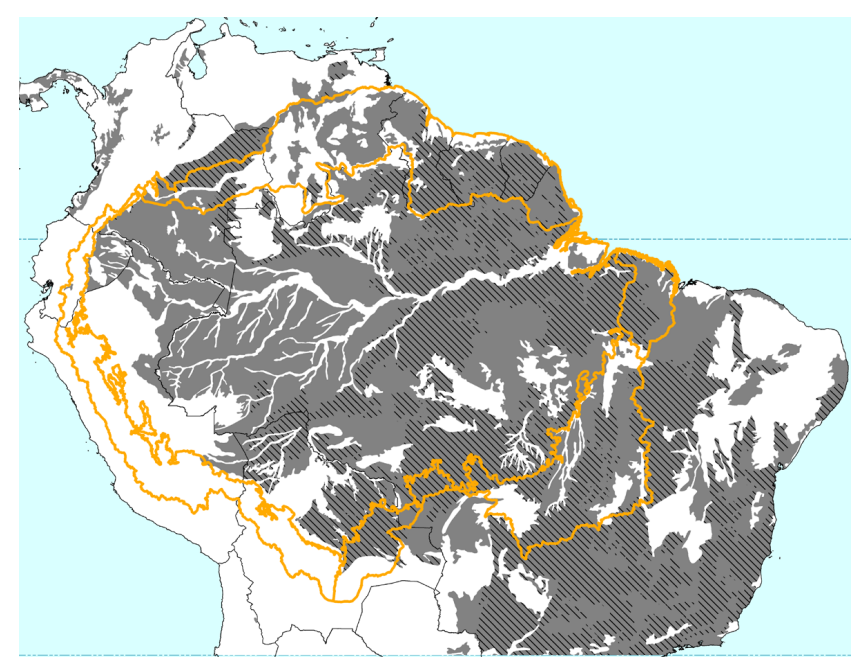

Fig. 3. Map of low-activity soils in tropical South America (57.0\% of the area, Batjes, 2010) ( $\square$ ), overlaid by shading indicating the occurrence of Ferralsols (= Oxisols, $29.2 \%$, Dijkshoorn et al., 2005) (.M). National borders and the outline of Amazonia sensu stricto are also shown (Eva et al., 2005).

type across all tropical South America, a mean was assigned from the low- or high-activity soil area of Batjes (2010). This type of calculation is an alternative to smooth interpolation algorithms such as kriging (e.g. Castanho et al., 2013) and is appropriate when extrapolating according to a categorical variable such as soil type which displays spatial step changes in value.

All soil hydraulic parameters were estimated across tropical South America using PTFs (Table 2). PTFs based on tropical soil profiles were used for all quantities (Tomasella and Hodnett, 1998; Hodnett and Tomasella, 2002) except $k_{\text {sat }}$, for which we have been unable to find any continuous, tropically based PTF (Tomasella and Hodnett, 2004; Rasoulzadeh, 2011; Pan et al., 2012), so we applied instead the most widely used temperate PTF (from Cosby et al., 1984). Values were calculated on a profile-by-profile basis and then assigned to polygons containing those points using the same rules as for the base measurements. These map layers were then converted to raster format at $15 \mathrm{arcsec}$ resolution and snapped to the HydroSHEDS digital elevation model (DEM) for South America, which is a high-resolution DEM that has had voids and anomalies removed (for details, see Lehner et al., 2006).

\section{Results}

Parameter maps are available for download for all soil quantities in raster GeoTIFF and NetCDF formats at 15 arcsec resolution (approximately $450 \mathrm{~m}$ at the Equator) from http://doi.org/10/r6p, with all NetCDF files conforming to
Climate and Forecast (CF) conventions. Considering the soil quantities from Table 2 in order:

- The saturated hydraulic conductivity $k_{\text {sat }}$ is lower across the Amazon Basin than it is across the Cerrado (Fig. 4a), with mean across the domain $k_{\mathrm{sat}}=0.008 \mathrm{~mm} \mathrm{~s}^{-1} \quad(n=1902$ SOTERLAC polygons), which is comparable to the $k_{\mathrm{sat}}=0.010 \mathrm{~mm} \mathrm{~s}^{-1}$ typical value for a microaggregated clay soil under tropical forest in Panama (Marthews et al., 2008). A reminder: this is a value for surface soil $<30 \mathrm{~cm}$ depth (as are all other values given here) and $k_{\text {sat }}$ usually decreases with depth (Elsenbeer et al., 1999; Clark and Gedney, 2008).

From the Tomasella and Hodnett (1998) PTFs:

- Parameter $b$ is broadly a measure of the steepness of the SWC (freely draining sandy soils generally have low values of $b$ (high values of $\lambda$ ) whereas heavy clay soils have high $b$ values). Values derived for tropical South America are uniformly lower (mean $=4.8$ ) than those derived from applying the Cosby et al. (1984) PTF for $b($ mean $=6.9)$.

- The air-entry potential $\psi_{\mathrm{e}}$ is the matric potential $\psi$ at which the soil first desaturates when drying after heavy rainfall (i.e. at which the largest pores drain). Values derived for tropical South America are less negative $($ mean $=-1.1 \mathrm{kPa})$ than those derived from applying the Cosby et al. (1984) PTF for $\psi_{\mathrm{e}}($ mean $=-2.5 \mathrm{kPa})$.

- The residual soil water content $\theta_{\text {res }}$ values are generally much lower $\left(\right.$ mean $=0.04 \mathrm{~cm}^{3} \mathrm{~cm}^{-3}$ ) than the $0.1866 \mathrm{~cm}^{3} \mathrm{~cm}^{-3}$ value suggested by Tomasella et al. (2000, Table 3) for Brazilian soils.

- The saturated soil water content $\theta_{\text {sat }}$ values are generally higher $\left(\right.$ mean $=0.51 \mathrm{~cm}^{3} \mathrm{~cm}^{-3}$ ) than those derived from applying the corresponding Cosby et al. (1984) PTF (mean $=0.43 \mathrm{~cm}^{3} \mathrm{~cm}^{-3}$ ) and closely match the $0.502 \mathrm{~cm}^{3} \mathrm{~cm}^{-3}$ value suggested by Tomasella et al. (2000, Table 3) for Brazilian soils.

- Using the parameter correspondences of MorelSeytoux et al. (1996, Table 1), estimated values for the van Genuchten-Mualem model may also be calculated from these PTFs, giving mean $n_{\mathrm{M}}=1.21 \alpha=$ $0.53 \mathrm{~m}^{-1}$.

From the Hodnett and Tomasella (2002) PTFs:

- The van Genuchten parameter $n_{M}$ is broadly a measure of how uniform are pore sizes in the soil and this gives $n_{\mathrm{M}}$ values slightly lower (mean $=1.47$, Fig. $4 \mathrm{~b}$ ) than the 1.571 value suggested by Tomasella et al. (2000, Table 3) for Brazilian soils. In deeper soil layers, $n_{\mathrm{M}}$ should increase (assuming SOC decreases with depth in the PTF of Hodnett and Tomasella, 2002). 

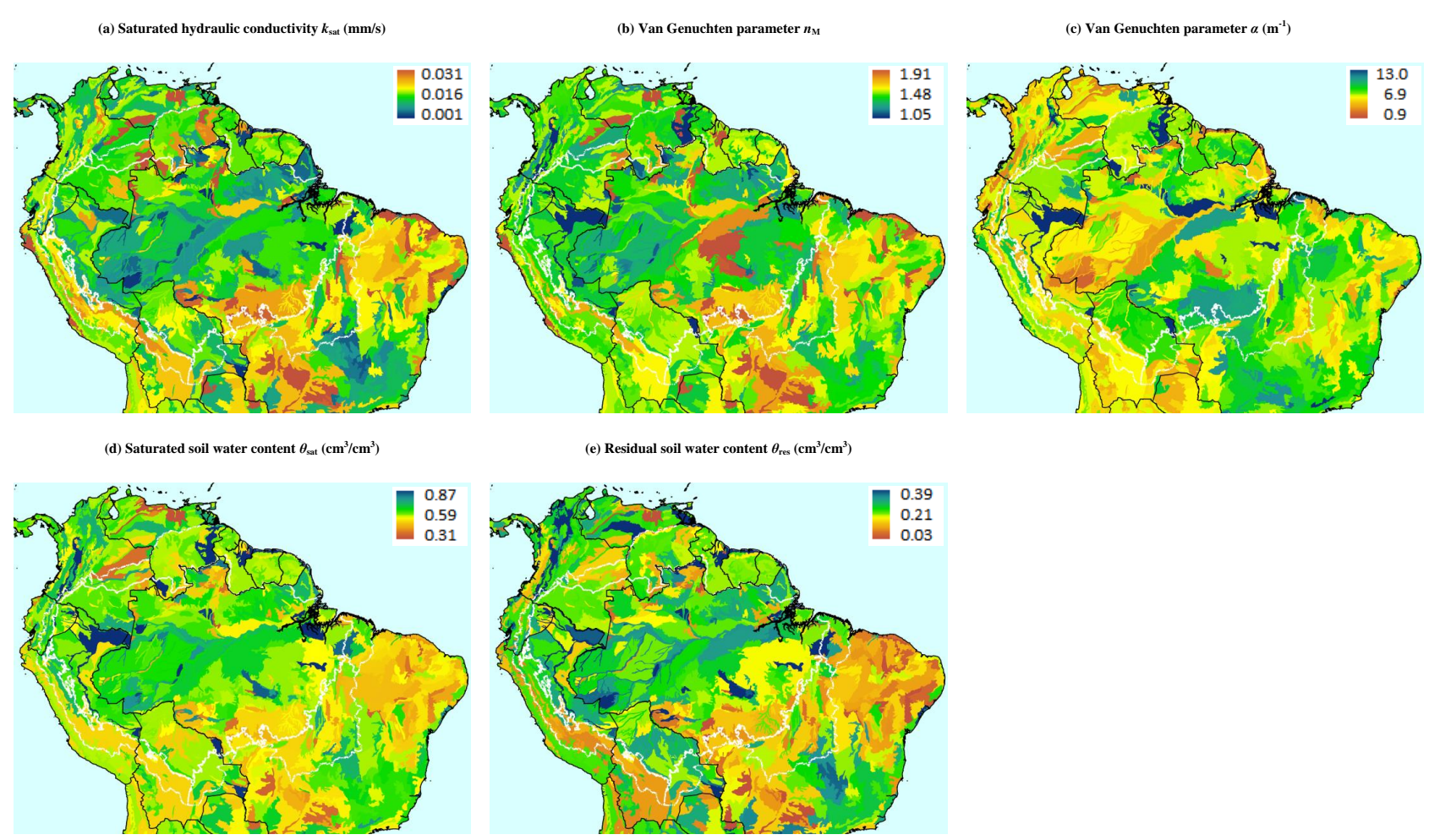

Fig. 4. Soil hydraulic parameter maps for tropical South America derived from the PTFs of Cosby et al. (1984) (a) and Hodnett and Tomasella (2002) (b-e): (a) saturated hydraulic conductivity $k_{\text {sat }}\left(\mathrm{mm} \mathrm{s}^{-1}\right)$, (b) Van Genuchten parameter $n_{\mathrm{M}}$, (c) Van Genuchten parameter $\alpha\left(\mathrm{m}^{-1}\right)$, (d) saturated soil water content $\theta_{\mathrm{sat}}\left(\mathrm{cm}^{3} \mathrm{~cm}^{-3}\right)$ and (e) residual soil water content $\theta_{\text {res }}\left(\mathrm{cm}^{3} \mathrm{~cm}^{-3}\right)$. National borders and the outline of Amazonia sensu stricto are also shown (Eva et al., 2005). For example, the calculated values given for Tambopata (Table 2) were from an area in SE Peru with unusually high residual and saturated soil water content in its soils and maps (c) and (d) give an indication of where soils of similar hydraulic properties may be found elsewhere in the region.

- The van Genuchten parameter $\alpha$ is broadly a measure of how structured the soil is and this gives $\alpha$ values much lower (mean $=3.1 \mathrm{~m}^{-1}$, Fig. 4c) than the $\rho g \times(1.0631 / 1000)=10.4 \mathrm{~m}^{-1}$ value suggested by Tomasella et al. (2000, Table 3) for Brazilian soils. In deeper soil layers, $\alpha$ should decrease (assuming SOC decreases with depth in the PTF of Hodnett and Tomasella, 2002).

- The residual soil water content $\theta_{\text {res }}$ values are much higher (mean $=0.19 \mathrm{~cm}^{3} \mathrm{~cm}^{-3}$, Fig. 4d) than those derived from applying the corresponding Tomasella and Hodnett (1998) PTF (mean $=0.04 \mathrm{~cm}^{3} \mathrm{~cm}^{-3}$ ), closely matching the $0.1866 \mathrm{~cm}^{3} \mathrm{~cm}^{-3}$ value suggested by Tomasella et al. (2000, Table 3) for Brazilian soils. In deeper soil layers, $\theta_{\text {res }}$ should be approximately the same as the surface value (neither DBD nor SOC are in the PTF of Hodnett and Tomasella, 2002).

- The saturated soil water content $\theta_{\text {sat }}$ values are slightly lower (mean $=0.48 \mathrm{~cm}^{3} \mathrm{~cm}^{-3}$, Fig. 4e) than those derived from applying the corresponding Tomasella and Hodnett (1998) PTF (mean $=0.51 \mathrm{~cm}^{3} \mathrm{~cm}^{-3}$ ) and slightly lower than the $0.502 \mathrm{~cm}^{3} \mathrm{~cm}^{-3}$ value suggested by Tomasella et al. (2000, Table 3) for Brazilian soils. In deeper soil layers, $\theta_{\text {sat }}$ should decrease (assuming DBD increases with depth in the PTF of Hodnett and Tomasella, 2002).

Over tropical South America the Hodnett and Tomasella (2002) PTFs give values that appear to be a great improvement over those from Cosby et al. (1984) and Tomasella and Hodnett (1998) (mean SWC curves based on these for standard USDA soil textural classes are given in Hodnett and Tomasella (2002), if required). Therefore, we recommend these functions whenever data are available for their implementation.

\section{Discussion}

Our study domain is all of tropical South America, covering all or part of 13 countries. We have also covered the entirety of the Amazon Basin - the most intensely studied part of the tropics - and the whole of the Amazon forest biome (containing approximately $50 \%$ of global tropical forests and $>50 \%$ of all species that exist on Earth) as well as some $20 \%$ of the world's freshwater resources (Malhi and Wright, 2004). 
Tropical South America is a critically important region and methods shown to work well here will set the standard for many other areas of the world.

Land surface models are being applied at ever increasing spatial resolution as a means to model ecosystem productivity and development as realistically as possible (Malhi and Wright, 2004; Marthews et al., 2008; Ke et al., 2012). Characterising soil physical properties is a key element in modelling land surface-atmosphere exchange processes and, therefore, critical to the successful application of coupled land surface models. The van Genuchten-Mualem model is the current de facto standard soil hydraulic model (Vereecken et al., 2010) and the downloadable data sets provided by this paper are sufficient to parameterise this model across tropical South America, as well as to parameterise three widely implemented alternatives (Table 1). The maps provided here are of $20 \times$ higher resolution than the 5 arcmin resolution IGBPDIS parameter maps, which are the best previously available (Global Soil Data Task Group, 2000; also see Ashton, 2012) and based on high-quality field data (Quesada et al., 2010) and the most comprehensive soil survey to date for South America (SOTERLAC, Dijkshoorn et al., 2005) and the latest PTFs from field data (Hodnett and Tomasella, 2002).

\subsection{Improving model parameterisation}

As with all models, soil hydraulics models can only be as good as their parameterisation from field data (see discussions in McBratney et al., 2002; Vereecken et al., 2010; Ke et al., 2012). By producing high-quality parameter maps based on pedotransfer functions (PTFs) that are (i) more sophisticated than simple texture-based PTFs (Table 2, specifically including dependence on cation exchange capacity (CEC) which can account at least partially for microaggregation effects) and were (ii) derived from local soil profiles in tropical South America (Hodnett and Tomasella, 2002), these parameter values are as robust as possible using currently available data sources. Additionally, the approach and tools we have developed are applicable, with the substitution of locally derived PTFs, in all other areas of the globe.

Uncertainties in all predicted quantities are given following the estimates quoted in our sources (see Table 2). Note that because many model simulations using these layers may be run at coarser resolution than 15 arcsec (e.g. climate models, usually run at resolutions of at least $0.5^{\circ}$ ), an aggregation step may be required to produce layers in a model-ready format: Aggregation may introduce uncertainties in addition to the base uncertainty of our layers (given in Table 2), dependent on the aggregation algorithm used.

\subsection{The wider context: future model development}

The soil hydraulic models presented in Table 1 are the current state of the art, and all can describe soil water movement well in many soils. However, they are not without limitations and improving these models is an active area of research (e.g. Vereecken et al., 2010; Fredlund et al., 2012). The value of the detailed parameter maps presented in this study would be greatly enhanced if progress could be made on four widely recognised model improvements in particular:

Improved modelling of macropore flow. Macropore flow is dictated by soil macrostructure rather than microstructure or texture and there is a recognised deficit of knowledge in this area (Lin et al., 2010). For example, the assumption of a unimodal pore-size distribution in standard soil hydraulics models is a significant barrier to further progress (Durner, 1994; Vereecken et al., 2010), especially in areas where microaggregated soils are common (Hodnett and Tomasella, 2002). Modelling macropore flow is especially important for characterising nutrient retention and leaching effects and improving the model representation of real, bimodal soil pore-size distributions could greatly improve the simulation of soil water movement in general (see e.g. Durner, 1994; Kutílek, 2004; Schaap and van Genuchten, 2006; Russell, 2010; Schelle et al., 2010; Zeiliguer et al., 2010; Vereecken et al., 2010; Lin et al., 2010). For example, models describing dual-porosity or double-porosity media in the context of flow through fractured rocks may be used to describe bypass and capillary flow in soil columns (Gerke and van Genuchten, 1993; Adler et al., 2005; Guarracino and Monachesi, 2010). In the case where it is unfeasible to move to a multimodal pore-size distribution model, the use of a parameterisation PTF that includes CEC would nevertheless be a significant improvement because that avoids grouping low- and highactivity clays together, resulting in a more realistic placing of the modal pore-size and therefore improved simulations of microaggregated soils where they occur.

Improved modelling of very dry soil. Soil that is exposed to direct sunlight and is within tens of $\mathrm{cm}$ of the surface can become much drier than permanent wilting point (PWP, Fig. 2) and this can occur frequently under natural conditions even in humid forests, for example during short dry spells in a wet season (Marthews et al., 2008). In very dry soil, the liquid water content is no longer continuous so capillary forces become negligible and the strength of adsorptive forces controls water retention (Vereecken et al., 2010; Fredlund et al., 2012). Standard soil hydraulics models do not model these effects well, simply assuming that a certain amount $\theta_{\text {res }}$ of soil water is "unavailable" to plants (Table 1) even though this approach has clear limitations (Durner, 1994; Vereecken et al., 2010). Improving the model representation of desorptive drying in very dry soil could greatly improve the simulation of soil water movement in general (see e.g. Sillers and Fredlund, 2001; Schelle et al., 2010; Vereecken et al., 2010; Fredlund et al., 2012). This is especially important in environments that are semi-arid or have a pronounced dry season.

Improved modelling of tortuosity. The pore-size distribution (PSD) describes the porosity of the soil (the proportion of micropores and macropores) but how they connect to each other through the soil is described by a pore 
connectivity model (PCM) and the current almost-universal standard PCM remains that of Mualem (1976). Mualem's PCM included tortuosity as an exponent (parameter $L$ ) and work in this area since then has mostly concentrated on deducing or fitting optimal values for $L$ (see Table 1). However, it should be remembered that Mualem (1976)'s study of 45 soils only included two clays and three clay loams and no tropical soils at all. Despite its wide use, it seems premature to assume that the Mualem PCM's functional form is optimal for all soil types, and we note that alternative PCMs do exist (see reviews in Dullien, 1992; Kutílek, 2004).

Inclusion of deeper soil layers. The general worldwide lack of soil hydraulic data from below approximately $1.5 \mathrm{~m}$ depth, especially regarding hydraulic conductivity, is currently an issue of great importance in soil science and remains a major impediment to the modelling of water movement and uptake in deep-rooted ecosystems such as tropical forests and savannas (Hodnett and Tomasella, 2002). In tropical South America, for example, there remains today an almost complete lack of soil profile data from deep soils (M. Hodnett, personal communication, 2013) because of the difficulty in extracting uncompacted and otherwise undisturbed soil cores (see discussion of field methods in Marshall et al., 1996; Dirksen, 2001, although some protocols do extend to deeper layers, e.g. RAINFOR-GEM soil sampling to $4 \mathrm{~m}$, Marthews et al., 2012). In the absence of data from deeper layers, extrapolations are usually made based on topsoil properties, but this is uncertain because of the usually greater compaction of subsoils and the possible presence of markedly different soil layers (e.g. acidic or sodic layers, impermeable layers at shallow depth, Marshall et al., 1996; Lloyd et al., 2009). Some soil parameters are generally assumed to remain constant with depth (e.g. $\lambda$ ) and others assumed to decrease exponentially (e.g. $k_{\mathrm{sat}}$, Clark and Gedney, 2008; although note that in many soils $k_{\text {sat }}$ actually increases with depth, e.g. saprolite layers or carbonate outcrops that have undergone karstification), but a full hydropedological survey is required to accurately describe the hydraulic properties of a soil profile at all depths.

In this study we have restricted our analysis to $30 \mathrm{~cm}$ soil depth because of the need for a consistent data base to extrapolate over a continental area, however understanding the soil sub-surface can nevertheless be crucial. For example, soils in the Acrisols group (Alisols, Luvisols, Lixisols and Acrisols), which cover $\sim 30 \%$ of Amazonia, have a typical two-layer vertical particle size distribution, being quite sandy in the top soil and clay rich in the subsoil (usually just below $30 \mathrm{~cm}$ ). For such soils, the parameter estimates and model fits presented in this study apply only to the upper layers and the effects of the lower layers should be accounted for separately.

Despite their sophistication in above-ground aspects, land surface models struggle to simulate systems where subsurface flow decouples deeper soil layers hydrologically from upper layers, thereby greatly affecting estimates of ecosystem resilience in the long term (e.g. see Elsenbeer et al., 1999 and discussions in Lloyd et al., 2009 and Dadson et al., 2011). A recent example of this is the "Australian Evergreen Paradox" where the marked dry season of the northern Australian monsoon tropics would lead a land surface model to predict dominance by deciduous tree species, while the actual dominance by evergreen species is a consequence of deep-water aquifers (Bowman and Prior, 2005).

\subsection{Spatial patterns of ecosystem function}

Soil properties and the dynamics of soil water movement are a fundamental control on the development and productivity of all ecosystems (Lloyd et al., 2009), e.g. Aragão et al. (2009) drew attention to edaphic controls on forest productivity in the Amazon Basin. However, there is a need to separate out which particular soil properties affect vegetation and forest structure in a region such as tropical South America (Quesada et al., 2010, 2011, 2012). Land surface models are an ideal tool for this task because they are process-based and can be used to isolate individual causes and effects, but the current generation of land surface models struggles to address this task at continental scales (e.g. Castanho et al., 2013). We believe that the problem may not be a lack of sophistication in these models, but - more simply - uncertainties involved in the parameter values used to calibrate them.

For example, it is known that sites in western Amazonia with younger, more fertile soils often have poorer physical properties than sites in central and eastern Amazonia with older, highly weathered soils (e.g. shallower soil depth, lower drainage capacity, Quesada et al., 2010, 2012) and this has been correlated with variation in floristic composition and tree turnover rates across the Amazon Basin (Phillips et al., 2004; Quesada et al., 2012). Similarly, in NE Amazonia generally tree wood is denser and seeds are larger, which has been correlated with the poorer soils that also occur there (ter Steege et al., 2006). However, it is not easy to separate cause and effect here: for example, younger soils are not always more fertile than older soils, and correlations between tree turnover rates and soil physical properties are always potentially confounded with uncontrollable factors such as restricted species ranges and carbon fertilisation rates (see discussions in Phillips et al., 2004 and Ashton, 2004). Some soil properties show a broad east-west variation (e.g. highvs. low-activity clays, Fig. 3), but other parameters present a more complex spatial pattern - notably soil hydraulic parameters, as shown in this paper (Fig. 4). Spatial patterns such as these imply complex spatial variation in forest dynamics that can only be described very superficially by the current generation of land surface models. Investigations of the causes of these little-studied spatial patterns requires high-resolution ancillary files exactly like those presented here. 


\section{Conclusions}

With recent improvements in the availability of spatial soil data grids (e.g. SOTER, Dijkshoorn et al., 2005) and improved region-specific PTFs (Tomasella and Hodnett, 2004), it has become possible to generate regional parameter maps for all models of soil hydraulics at high resolution. In this paper we have produced gridded data sets for tropical South America that are a step improvement on the best comparable maps currently available to the public.

Variation in soil hydraulic parameters may explain less of the known variation in forest dynamics and ecosystem productivity across tropical South America than other factors such as species-specific responses (Leigh, 1999; ter Steege et al., 2006) or climate (e.g. Malhi and Wright, 2004; Lloyd et al., 2009). However, it does seem clear that we currently know far too little about the portion of that variation that is under the control of these parameters. We recognise a pressing need for improved understanding of the various processes that control soil water dynamics, especially soil structural and microstructural aspects of tropical soils. There is also a need for soil data sets that extend profile information to depths of at least $1.5 \mathrm{~m}$ in order both to include a greater proportion of the rooting zone and to determine where and when reduced saturated hydraulic conductivity causes lateral flow.

Land surface models are experiencing a time of rapid development, but in some ways code development has progressed more quickly than development of the parameterisations on which code simulations are based (e.g. Ke et al., 2012). The time is right for a strong improvement in the quality of parameterisation behind these models, which will lead to much more robust simulations of soil water dynamics and, ultimately, greatly improved vegetation and biome productivity predictions for the tropical zone as a whole.

Acknowledgements. This study is a product of the Andes Biodiversity and Ecosystem Research Group (ABERG, http://www.andesconservation.org/) and has drawn heavily on its collaborators, infrastructure and data sources. We are indebted to the Gordon and Betty Moore Foundation (grant to RAINFOR) and the Jackson Foundation and Oxford Martin School (grants to Y. Malhi). C. A. Quesada was supported in part by the European Union Fifth Framework Programme as part of CARBONSINKLBA, part of the European contribution to the Large-Scale Biosphere-Atmosphere Experiment in Amazonia (LBA), and by the Gordon and Betty Moore Foundation. Thanks to J. Schmerler, M. Schwartz, G. Lloyd, G. Borges, E. Oblitas, J. Morais Filho, R. Araújo Filho and O. Ferreira Cruz Junior for their field and laboratory assistance. Thanks to S. Abele for help with Python code and mapping and P. Tempel, A. Zeiliguer, G. Hill and J. Lloyd for helpful discussions during development. Finally, huge thanks to I. Perzia for continued support in every way during the writing of this paper.

Edited by: O. Marti

\section{References}

Adler, P. M., Mourzenko, V. V., Thovert, J. and Bogdanov, I.: Study of Single and Multiphase Flow in Fractured Porous Media, Using a Percolation Approach, in: Dynamics of Fluids and Transport in Fractured Rock, edited by: Faybishenko, B., Witherspoon, P. A., and Gale, J., American Geophysical Union, Washington, DC, 33-41, 2005.

Aragão, L. E. O. C., Malhi, Y., Metcalfe, D. B., Silva-Espejo, J. E., Jiménez, E., Navarrete, D., Almeida, S., Costa, A. C. L., Salinas, N., Phillips, O. L., Anderson, L. O., Alvarez, E., Baker, T. R., Goncalvez, P. H., Huamán-Ovalle, J., Mamani-Solórzano, M., Meir, P., Monteagudo, A., Patiño, S., Peñuela, M. C., Prieto, A., Quesada, C. A., Rozas-Dávila, A., Rudas, A., Silva Jr., J. A., and Vásquez, R.: Above- and below-ground net primary productivity across ten Amazonian forests on contrasting soils, Biogeosciences, 6, 2759-2778, doi:10.5194/bg-6-2759-2009, 2009.

Ashton, H.: New Soil Physical Properties Implemented into the UKPP MOSES- PDM-RFM at PS25, Weather Science Technical Report, 563, Met Office, UK, 2012.

Ashton, P. S.: Soils in the Tropics, in: Tropical Forest Diversity and Dynamism, edited by: Losos, E. C. and Leigh, E. G., University of Chicago Press, Chicago, Illinois, 56-68, 2004.

Batjes, N. H.: Global Soil Profile Data (International Soil Reference and Information Centre - World Inventory of Soil Emission Potentials), Data set, Oak Ridge National Laboratory Distributed Active Archive Center, Oak Ridge, Tennessee, 2000.

Batjes, N. H.: IPCC default soil classes derived from the Harmonized World Soil Data Base (version 1.1), Report 2009/02b, Carbon Benefits Project (CBP) and ISRIC - World Soil Information, Wageningen, Netherlands, 2010.

Best, M. J., Pryor, M., Clark, D. B., Rooney, G. G., Essery, R. L. H., Ménard, C. B., Edwards, J. M., Hendry, M. A., Porson, A., Gedney, N., Mercado, L. M., Sitch, S., Blyth, E., Boucher, O., Cox, P. M., Grimmond, C. S. B., and Harding, R. J.: The Joint UK Land Environment Simulator (JULES), model description Part 1: Energy and water fluxes, Geosci. Model Dev., 4, 677-699, doi:10.5194/gmd-4-677-2011, 2011.

Bowman, D. M. J. S. and Prior, L. D.: Why do evergreen trees dominate the Australian seasonal tropics?, Aust. J. Bot., 53, 379-399, 2005.

Brooks, R. H. and Corey, A. T.: Hydraulic properties of porous media, Colo. Colo. St. Hydrol. Papers, 3, 1-30, 1964.

Burdine, N. T.: Relative permeability calculations from pore size distribution data, T. Am. Inst. of Mineralogy, Metallurgical and Petroleum Engineers, 198, 71-78, 1953.

Campbell, G. S.: A simple method for determining unsaturated conductivity from moisture retention data, Soil Sci., 117, 311-314, 1974.

Campbell, G. S.: Soil physics with BASIC, Elsevier, Amsterdam, Netherlands, 1985.

Castanho, A. D. A., Coe, M. T., Costa, M. H., Malhi, Y., Galbraith, D., and Quesada, C. A.: Improving simulated Amazon forest biomass and productivity by including spatial variation in biophysical parameters, Biogeosciences, 10, 2255-2272, doi:10.5194/bg-10-2255-2013, 2013.

Childs, E. C.: An Introduction to the Physical Basis of Soil Water Phenomena, Wiley, London, UK, 1969. 
Clapp, R. B. and Hornberger, G. M.: Empirical Equations for Some Soil Hydraulic Properties, Water Resour. Res., 14, 601-604, 1978.

Clark, D. B. and Gedney, N.: Representing the effects of subgrid variability of soil moisture on runoff generation in a land surface model, J. Geophys. Res. D, 113, D10111, doi:10.1029/2007JD008940, 2008.

Cooper, M., Mendes, L. M. S., Silva, W. L. C., and Sparovek, G.: A national soil profile database for Brazil available to international scientists, Soil. Sci. Soc. Am. J., 69, 649-652, 2005.

Cosby, B. J., Hornberger, G. M., Clapp, R. B., and Ginn, T. R.: A Statistical Exploration of the Relationships of Soil Moisture Characteristics to the Physical Properties of Soils, Water Resour. Res., 20, 682-690, 1984.

Dadson, S. J. and Bell, V. A.: Comparison of Grid-2-Grid and TRIP runoff routing schemes, Report, Centre for Ecology and Hydrology, Wallingford, UK, available at: http://nora.nerc.ac.uk/10890/ (last access: 1 May 2014), 2010.

Dadson, S. J., Bell, V. A., and Jones, R. G.: Evaluation of a gridbased river flow model configured for use in a regional climate model, J. Hydrol., 411, 238-250, 2011.

de Negreiros, G. H., Alencar, A. C., Schlesinger, P., Nepstad, D. C., and Lefebvre, P. A.: Pre-LBA RADAMBRASIL Project Data, Data set, Oak Ridge National Laboratory Distributed Active Archive Center, Oak Ridge, Tennessee, 2009.

de Rosnay, P., Bruen, M., and Polcher, J.: Sensitivity of surface fluxes to the number of layers in the soil model used in GCMs, Geophys. Res. Lett., 27, 3329-3332, 2000.

Dharssi, I., Vidale, P. L., Verhoef, A., Macpherson, B., Jones, C., and Best, M.: New soil physical properties implemented in the Unified Model at PS18, Met Office Technical Report, 528, 2009.

Dijkshoorn, J. A., Huting, J. R. M., and Tempel, P.: Update of the 1:5 million Soil and Terrain Database for Latin America and the Caribbean (SOTERLAC; version 2.0), Report 2005/01, ISRIC World Soil Information, Wageningen, Netherlands, 2005.

Dirksen, C.: Unsaturated Hydraulic Conductivity, in: Soil and Environmental Analysis: Physical Methods, edited by: Smith, K. A. and Mullins, C. E., Marcel Dekker, New York, 2nd Edn., 183237, 2001

Dullien, F. A. L.: Porous Media Fluid Transport and Pore Structure, Academic Press, San Diego, California, 2nd Edn., 1992.

Durner, W.: Hydraulic conductivity estimation for soils with heterogeneous pore structure, Water Resour. Res., 30, 211-223, 1994.

Elsenbeer, H., Newton, B. E., Dunne, T., and de Moraes, J. M.: Soil hydraulic conductivities of latosols under pasture, forest and teak in Rondonia, Brazil, Hydrol. Process., 13, 1417-1422, 1999.

European Centre for Medium-Range Weather Forecasts: IFS documentation CY33r1 part IV: physical processes, ECMWF document, available at: http://www.ecmwf.int/research/ifsdocs/ CY33r1/PHYSICS/IFSPart4.pdf (last access: 1 May 2014), 2009.

Eva, H. D., Huber, O., Achard, F., Balslev, H., Beck, S., Behling, H., Belward, A. S., Beuchle, R., Cleef, A., Colchester, M., Duivenvoorden, J., Hoogmoed, M., Junk, W., Kabat, P., Kruijt, B., Malhi, Y., Müller, J. M., Pereira, J. M., Peres, C., Prance, G. T., Roberts, J., and Salo, J.: A proposal for defining the geographical boundaries of Amazonia, Report, European Communities, Luxembourg, 2005.
Fredlund, D. G., Rahardjo, H., and Fredlund, M. D.: Unsaturated Soil Mechanics in Engineering Practice, Wiley, Hoboken, New Jersey, 2012.

Gerke, H. H. and van Genuchten, M. T.: A Dual-Porosity Model for Simulating the Preferential Movement of Water and Solutes in Structured Porous Media, Water Resour. Res., 29, 305-319, 1993.

Global Soil Data Task Group: Global Gridded Surfaces of Selected Soil Characteristics (IGBP-DIS), Data set, Oak Ridge National Laboratory Distributed Active Archive Center, Oak Ridge, Tennessee, 2000.

Guarracino, L. and Monachesi, L. B.: Numerical simulation of constitutive relations for unsaturated flow in fractured porous media, 18th International Conference on Computational Methods in Water Resources, Barcelona, Spain, available at: http://congress.cimne.com/cmwr2010/Proceedings/docs/ p143.pdf, 21-24 June 2010,

Hodnett, M. G. and Tomasella, J.: Marked differences between van Genuchten soil water-retention parameters for temperate and tropical soils: a new water-retention pedo-transfer functions developed for tropical soils, Geoderma, 108, 155-180, 2002.

Jones, C. P.: Ancillary file data sources (v.10), Unified Model Documentation Paper 70, 1-37, available at: http://collab.metoffice. gov.uk/twiki/pub/Support/Umdp/070_66.pdf, 2008.

Ke, Y., Leung, L. R., Huang, M., Coleman, A. M., Li, H., and Wigmosta, M. S.: Development of high resolution land surface parameters for the Community Land Model, Geosci. Model Dev., 5, 1341-1362, doi:10.5194/gmd-5-1341-2012, 2012.

Kutílek, M.: Soil hydraulic properties as related to soil structure, Soil Till. Res., 79, 175-184, 2004.

Lehner, B., Verdin, K., and Jarvis, A.: HydroSHEDS Technical Documentation (Version 1.0), World Wide Fund for Nature, Washington, DC, 2006.

Leigh, E. G.: Tropical forest ecology A View from Barro Colorado Island, OUP, New York, 1999.

Lin, H., Flühler, H., Otten, W. and Vogel, H.-J.: Soil architecture and preferential flow across scales, J. Hydrol., 393, 1-2, 2010.

Lloyd, J., Goulden, M. L., Ometto, J. P., Patiño, S., Fyllas, N. M., and Quesada, C. A.: Ecophysiology of Forest and Savanna Vegetation, in: Amazonia and Global Change, edited by: Keller, M., Bustamante, M., Gash, J., and Silva Dias, P., American Geophysical Union, Washington, DC, 463-484, 2009.

Malhi, Y. and Wright, J.: Spatial patterns and recent trends in the climate of tropical rainforest regions, Philos. Trans. R. Soc. Lond. B, 359, 311-329, 2004.

Marshall, T. J., Holmes, J. W., and Rose, C. W.: Soil Physics, CUP, Cambridge, UK, 3rd Edn., 1996.

Marthews, T. R., Burslem, D. F. R. P., Paton, S. R., Yangüez, F. and Mullins, C. E.: Soil drying in a tropical forest: Three distinct environments controlled by gap size, Ecol. Model., 216, 369384, 2008.

Marthews, T. R., Metcalfe, D., Malhi, Y., Phillips, O., Huaraca Huasco, W., Riutta, T., Ruiz Jaén, M., Girardin, C., Urrutia, R., Butt, N., Cain, R., Oliveras Menor, I. and colleagues from the RAINFOR and GEM networks: Measuring Tropical Forest Carbon Allocation and Cycling: A RAINFOR-GEM Field Manual for Intensive Census Plots (v2.2), Manual, Global Ecosystems Monitoring network, available at: http://gem.tropicalforests.ox. ac.uk/page/resources, 2012. 
McBratney, A. B., Minasny, B., Cattle, S. R., and Vervoort, R. W.: From pedotransfer functions to soil inference systems, Geoderma, 109, 41-73, 2002.

Morel-Seytoux, H. J., Meyer, P. D., Nachabe, M., Touma, J., van Genuchten, M. T., and Lenhard, R. J.: Parameter equivalence for the Brooks-Corey and van Genuchten soil characteristics: Preserving the effective capillary drive, Water Resour. Res., 32, 1251-1258, 1996.

Mualem, Y.: A New Model for Predicting the Hydraulic Conductivity of Unsaturated Porous Media, Water Resour. Res., 12, 513522,1976

Mullins, C. E.: Matric Potential, in: Soil and Environmental Analysis: Physical Methods, edited by: Smith, K. A. and Mullins, C. E., Marcel Dekker, New York, 2nd Edn., 65-93, 2001.

Pan, F., McKane, R. B., and Stieglitz, M.: Identification of optimal soil hydraulic functions and parameters for predicting soil moisture, Hydrolog. Sci. J., 57, 723-737, 2012.

Pertassek, T., Peters, A., and Durner, W.: HYPROP Data Evaluation Software, User's Manual, Umwelt Monitoring Systeme GmbH, München, Germany, 2011.

Phillips, O. L., Hall, P., Gentry, A. H., Sawyer, S. A., and Vásquez, R.: Dynamics and species richness of tropical rain forests, Proc. Natl. Acad. Sci. USA, 91, 2805-2809, 1994.

Phillips, O. L., Baker, T. R., Arroyo, L., Higuchi, N., Killeen, T. J., Laurance, W. F., Lewis, S. L., Lloyd, J., Malhi, Y., Monteagudo, A., Neill, D. A., Núñez Vargas, P., Silva, J. N. M., Terborgh, J., Vásquez Martínez, R., Alexiades, M., Almeida, S., Brown, S., Chave, J., Comiskey, J. A., Czimczik, C. I., Di Fiore, A., Erwin, T., Kuebler, C., Laurance, S. G., Nascimento, H. E. M., Olivier, J., Palacios, W., Patiño, S., Pitman, N. C. A., Quesada, C. A., Saldias, M., Torres Lezama, A., and Vinceti, B.: Pattern and process in Amazon tree turnover, 1976-2001, Philos. Trans. R. Soc. Lond. B, 359, 381-407, 2004.

Quesada, C. A., Lloyd, J., Schwarz, M., Patiño, S., Baker, T. R., Czimczik, C., Fyllas, N. M., Martinelli, L., Nardoto, G. B., Schmerler, J., Santos, A. J. B., Hodnett, M. G., Herrera, R., Luizão, F. J., Arneth, A., Lloyd, G., Dezzeo, N., Hilke, I., Kuhlmann, I., Raessler, M., Brand, W. A., Geilmann, H., Moraes Filho, J. O., Carvalho, F. P., Araujo Filho, R. N., Chaves, J. E., Cruz Junior, O. F., Pimentel, T. P., and Paiva, R.: Variations in chemical and physical properties of Amazon forest soils in relation to their genesis, Biogeosciences, 7, 1515-1541, doi:10.5194/bg-7-15152010, 2010.

Quesada, C. A., Lloyd, J., Anderson, L. O., Fyllas, N. M., Schwarz, M., and Czimczik, C. I.: Soils of Amazonia with particular reference to the RAINFOR sites, Biogeosciences, 8, 1415-1440, doi:10.5194/bg-8-1415-2011, 2011.

Quesada, C. A., Phillips, O. L., Schwarz, M., Czimczik, C. I., Baker, T. R., Patiño, S., Fyllas, N. M., Hodnett, M. G., Herrera, R., Almeida, S., Alvarez Dávila, E., Arneth, A., Arroyo, L., Chao, K. J., Dezzeo, N., Erwin, T., di Fiore, A., Higuchi, N., Honorio Coronado, E., Jimenez, E. M., Killeen, T., Lezama, A. T., Lloyd, G., López-González, G., Luizão, F. J., Malhi, Y., Monteagudo, A., Neill, D. A., Núñez Vargas, P., Paiva, R., Peacock, J., Peñuela, M. C., Peña Cruz, A., Pitman, N., Priante Filho, N., Prieto, A., Ramírez, H., Rudas, A., Salomão, R., Santos, A. J. B., Schmerler, J., Silva, N., Silveira, M., Vásquez, R., Vieira, I., Terborgh, J., and Lloyd, J.: Basin-wide variations in Amazon forest struc- ture and function are mediated by both soils and climate, Biogeosciences, 9, 2203-2246, doi:10.5194/bg-9-2203-2012, 2012.

Rasoulzadeh, A.: Estimating Hydraulic Conductivity Using Pedotransfer Functions, in: Hydraulic Conductivity - Issues, Determination and Applications, edited by: Elango, L., InTech, Rijeka, Croatia, 145-164, 2011.

Russell, A. R.: Water retention characteristics of soils with double porosity, Eur. J. Soil Sci., 61, 412-424, 2010.

Schaap, M. G. and Leij, F. J.: Improved Prediction of Unsaturated Hydraulic Conductivity with the Mualem-van Genuchten Model, Soil. Sci. Soc. Am. J., 64, 843-851, 2000.

Schaap, M. G. and van Genuchten, M. T.: A Modified Mualemvan Genuchten Formulation for Improved Description of the Hydraulic Conductivity Near Saturation, Vadose Zone J., 5, 27-34, 2006.

Schelle, H., Iden, S. C., Peters, A., and Durner, W.: Analysis of the Agreement of Soil Hydraulic Properties Obtained from Multistep-Outflow and Evaporation Methods, Vadose Zone J., 9, 1080-1091, 2010.

Seki, K.: SWRC fit - a nonlinear fitting program with a water retention curve for soils having unimodal and bimodal pore structure, Hydrol. Earth Syst. Sci. Discuss., 4, 407-437, doi:10.5194/hessd-4-407-2007, 2007.

Shao, Y. and Irannejad, P.: On the choice of soil hydraulic models in land-surface schemes, Bound.-Lay. Meteorol., 90, 83-115, 1999.

Sillers, W. S. and Fredlund, D. G.: Statistical assessment of soilwater characteristic curve models for geotechnical engineering, Can. Geotech. J., 38, 1297-1313, 2001.

ter Steege, H., Pitman, N. C. A., Phillips, O. L., Chave, J., Sabatier D., Duque, A., Molino, J., Prévost, M., Spichiger, R., Castellanos, H., von Hildebrand, P., and Vásquez, R.: Continental-scale patterns of canopy tree composition and function across Amazonia, Nature, 443, 444-447, 2006.

Tomasella, J. and Hodnett, M. G.: Estimating soil water retention characteristics from limited data in Brazilian Amazonia, Soil Sci., 163, 190-202, 1998.

Tomasella, J. and Hodnett, M.: Pedotransfer functions for tropical soils, Dev. Soil Sci., 30, 415-429, 2004.

Tomasella, J., Hodnett, M. G., and Rossato, L.: Pedotransfer Functions for the Estimation of Soil Water Retention in Brazilian Soils, Soil. Sci. Soc. Am. J., 64, 327-338, 2000.

Tomasella, J., Pachepsky, Y., Crestana, S., and Rawls, W. J.: Comparison of Two Techniques to Develop Pedotransfer Functions for Water Retention, Soil. Sci. Soc. Am. J., 67, 1085-1092, 2003.

Townend, J., Reeve, M. J., and Carter, A.: Water Release Characteristic, in Soil and Environmental Analysis: Physical Methods, edited by: Smith, K. A., and C. E. Mullins, Marcel Dekker, New York, 2nd Edn., 95-140, 2001.

Valiantzas, J. D.: Combined Brooks-Corey/Burdine and van Genuchten/Mualem Closed-Form Model for Improving Prediction of Unsaturated Conductivity, J. Irrig. Drain. E., 137, 223 233, 2011.

van Genuchten, M. T.: A Closed-form Equation for Predicting the Hydraulic Conductivity of Unsaturated Soils, Soil. Sci. Soc. Am. J., 44, 892-898, 1980.

van Genuchten, M. T., Leij, F. J., and Yates, S. R.: The RETC Code for Quantifying the Hydraulic Functions of Unsaturated Soils, Environmental Protection Agency Report 600/2-91/065, United States Salinity Laboratory, Riverside, California, 1991. 
Vereecken, H., Weynants, M., Javaux, M., Pachepsky, Y., Schaap, M. G., and van Genuchten, M. T.: Using Pedotransfer Functions to Estimate the van Genuchten-Mualem Soil Hydraulic Properties: A Review, Vadose Zone J., 9, 795-820, 2010.

Wösten, J. H. M., Lilly, A., Nemes, A., and le Bas, C.: Development and use of a database of hydraulic properties of European soils, Geoderma, 90, 169-185, 1999.
Zeiliguer, A. M., Feddes, R., and Ermolaeva, O. S.: Estimating soil water retention in soil aggregates using an "additivity" model for combining structural and textural pore spaces, 19th World Congress of Soil Science, Soil Solutions for a Changing World, Brisbane, Australia, available at: http://www.iuss.org/ 19th\%20WCSS/Symposium/pdf/1522.pdf, 1-6 August 2010. 